\title{
Laboratory Investigation of Human Rhinovirus Infection in Cheonan, Korea
}

Bo Kyeung Jung ${ }^{1}$, Jae Kyung $\mathrm{Kim}^{2}$

${ }^{1}$ Department of Laboratory Medicine, Dankook University Hospital, Cheonan, Korea

${ }^{2}$ Department of Biomedical Laboratory Science, Dankook University College of Health Sciences, Cheonan, Korea

\section{7년간 천안지역 대학병원에서의 라이노바이러스 감염 양상에 대한 연구}

정보경 ${ }^{1}$, 김재경 ${ }^{2}$

${ }^{1}$ 단국대학교병원 진단검사의학과, ${ }^{2}$ 단국대학교 보건과학대학 임상병리학과

\section{ARTICLE INFO}

Received August 11, 2019

Revised $1^{\text {st }}$ August 29, 2019

Revised $2^{\text {nd }}$ September 3, 2019

Accepted September 3, 2019

\begin{abstract}
Annually, millions of children die from respiratory virus infections. Human rhinovirus (HRV) is a causative agent of severe respiratory infections in young, elderly, and asthmatic patients with weak immunity. In this study, 9,010 respiratory virus specimens were collected from January 2012 to December 2018 at Dankook University Hospital, Cheonan and examined by real-time reverse transcription polymerase chain reaction. Twelve respiratory viruses were detected. The mean detection rate was $21.3 \%(\mathrm{~N}=1,920 / 9,010)$, and the mean age of HRV-positive patients was 6.5 years (median age: 1.6 years, range: $0.0 \sim 96.0)$. The detection rate was the highest in July (32.4\%) and the lowest in February (8.3\%). When the detection rate was analyzed by age group, the detection rate was the second highest in patients aged $10 \sim 19$ years. The co-infection rate of HRV was $35.3 \%$, and the most common combination was with Adenovirus. Respiratory virus infections are known to occur in children and elderly people with weak immunity. However, in this study, the detection rate was second highest in patients aged 10 19 years. Indeed, the detection rate in this age group was more than 15\%, except in January and February. These results suggested that steady-state studies on the infection patterns of HRV are required.
\end{abstract}

Copyright ${ }^{\circledR} 2019$ The Korean Society for Clinical Laboratory Science. All rights reserved.

\section{INTRODUCTION}

Respiratory viruses are one of the most common infectious diseases in children, accounting for $30 \sim 50 \%$ of the total number of hospitalized patients worldwide, and are responsible for the deaths of millions of children each year [1, 2]. The major causative agents of respiratory virus

* Corresponding author: Jae Kyung Kim

Department of Biomedical Laboratory Science, Dankook University College of Health Sciences, 119 Dandae-ro, Dongnan-gu, Cheonan 31116, Korea

E-mail: nerowolf2@dankook.ac.kr

* ORCID: https://orcid.org/0000-0002-1534-563X infections are Adenovirus, Coronavirus, Human rhinovirus, Influenza $A$ and $B$ viruses, Metapneumovirus, Parainfluenza viruses (1 3), and Respiratory syncytial viruses $A$ and $B$.

Human rhinovirus (HRV) is a species of the Picornaviridae family, Enterovirus genus. HRV is currently classified into three species, HRV-A, -B, and -C, and there are more than 100 serotypes of HRVs [3]. Recent studies have reported that HRV-A and $-\mathrm{C}$ are detected more frequently than HRV-B. Real-time reverse transcription polymerase chain reaction (RT-PCR) can be used to detect all three species of HRV (HRV-A, -B, and -C). HRV is the 
most common cause of respiratory infections, regardless of age. Headache, sore throat, and cough are the main symptoms, and $50 \%$ of cold cases in adults are caused by HRV $[4,5]$. HRV has also been reported to cause severe respiratory infections in patients that are immunocompromised due to age, tumors, or asthma and can aggravate asthma, leading to chronic obstructive airway infection [6]. This virus is also associated with all types of upper and lower respiratory diseases, but is of particular concern when causing lower respiratory tract infections in children, infants, immunocompromised patients, and the elderly. Thus, because of the risk posed by these respiratory viruses, the Korea Center for Disease Control and Prevention (KCDC) has developed the Influenza and Respiratory Viruses Surveillance System (KINRESS), which includes surveillance of HRV [7].

In this study, we investigated the patterns of infection for HRV, including annual, monthly, and overlapping infections at a local university hospital for 7 years. Although common colds are not associated with major health concerns, they can result in enormous costs to society in the form of missed school and work and unnecessary medical care.

\section{MATERIALS AND METHODS}

\section{Collection of samples}

The patients in this study provided 9,010 respiratory specimens (nasopharyngeal aspirates, nasal swabs, and throat swabs), which were sent to the Department of Laboratory Medicine, Dankook University Hospital, Cheonan for real-time RT-PCR, from January 2012 to December 2018. The samples were immediately tested, or if they were not immediately available, they were refrigerated at $4^{\circ} \mathrm{C}$ and tested within $24 \mathrm{~h}$.

\section{Extraction of RNA}

The collected respiratory specimens were treated with a QIAamp MinElute Virus Spin Kit (Qiagen, Hilden, Germany) to extract the RNA.

\section{Synthesis of complementary DNA (cDNA)}

cDNA was synthesized using a RevertAid First Strand cDNA Synthesis Kit (Fermentas, Ontario, Canada). The reverse transcription reaction was performed by mixing 50 ng extracted RNA with random hexamers $(0.2 \mu \mathrm{g} / \mu \mathrm{L})$ at $25^{\circ} \mathrm{C}$ for $5 \mathrm{~min}$. RT buffer, $10 \mathrm{mM}$ dNTP, RNase inhibitor $(20 \mu \mathrm{g} / \mu \mathrm{L})$, and reverse transcriptase $(200 \mu \mathrm{g} / \mu \mathrm{L})$ were added to the mixture and reacted in a final reaction volume of $20 \mu \mathrm{L}$ at $42^{\circ} \mathrm{C}$ for $60 \mathrm{~min}$.

\section{Real-time RT-PCR}

Extracted nucleic acids were then amplified and probed for HRVs with the AdvanSure RV real-time RT-PCR (LG Life Science, Seoul, Korea) according to the manufacturer's instructions. Five microliters of extracted cDNA was added to a tube containing $5 \mu \mathrm{L}$ of primer probe mix and $10 \mu \mathrm{L}$ of one-step RT-PCR premix. For the reverse transcription step, this mixture was incubated at $50^{\circ} \mathrm{C}$ for 10 min. Denaturation was performed at $95^{\circ} \mathrm{C}$ for $30 \mathrm{~s}$, followed by 10 cycles of PCR $\left(15 \mathrm{~s}\right.$ at $95^{\circ} \mathrm{C}, 30 \mathrm{~s}$ at $53^{\circ} \mathrm{C}$, and $30 \mathrm{~s}$ at $60^{\circ} \mathrm{C}$ ). Thirty additional cycles of PCR were completed for the detection of fluorescence signals $(15 \mathrm{~s}$ at $95^{\circ} \mathrm{C}, 30 \mathrm{~s}$ at $53^{\circ} \mathrm{C}$, and $30 \mathrm{~s}$ at $60^{\circ} \mathrm{C}$.

\section{Statistical analysis}

HRV detected by real-time RT-PCR was analyzed by various criteria, including overlapping infection, sex, age, year, and month. Results with $P$ values of less than 0.05 were significant.

\section{Ethics}

This study was approved by the IRB Committee of Dankook University (No. 2019-04-006).

\section{RESULTS}

Among the 9,010 respiratory specimens collected during the study period, 12 respiratory viruses were detected in 5,081 specimens, with a detection rate of 56.4\%; 1,920 specimens were positive for HRV (detection 
rate: $21.3 \%$ ). The detection rate for males was $22.0 \%$ $(\mathrm{N}=1,155 / 5,242)$, and the detection rate for females was $20.3 \%(\mathrm{~N}=765 / 3,768)$. The average age of the patients was 19.8 years (median age: 2.7 years, range: $0.0 \sim 96.0$ years). The mean age of patients with HRV was 6.4 years (median age: 1.6 years, range: $0.0 \sim 93.2$ years) (Table 1 ).

The detection rate in 2015 was the highest (30.7\%; $\mathrm{N}=358 / 1165)$, and the second highest detection rate was in 2016 (27.4\%; N=365/1333). The detection rate in 2018

Table 1. Detection rate and number of specimen of HRV aggregated by month

\begin{tabular}{llccc}
\hline \multirow{2}{*}{ Month } & $\begin{array}{c}\text { Total } \\
\text { specimen (No.) }\end{array}$ & $\begin{array}{c}\text { Positive } \\
\text { specimen (No.) }\end{array}$ & $\begin{array}{c}\text { Detection } \\
\text { rate }(\%)\end{array}$ \\
\hline Spring & 3 & 887 & 174 & 19.6 \\
& 4 & 892 & 220 & 24.7 \\
\multirow{5}{*}{ Summer } & 5 & 814 & 219 & 26.9 \\
& 6 & 636 & 175 & 27.5 \\
& 7 & 590 & 191 & 32.4 \\
Autumn & 8 & 610 & 141 & 23.1 \\
& 9 & 543 & 169 & 31.1 \\
& 10 & 650 & 178 & 27.4 \\
& 11 & 829 & 188 & 22.7 \\
& 12 & 1058 & 136 & 12.9 \\
& 1 & 681 & 61 & 9.0 \\
& 2 & 820 & 68 & 8.3 \\
\hline
\end{tabular}

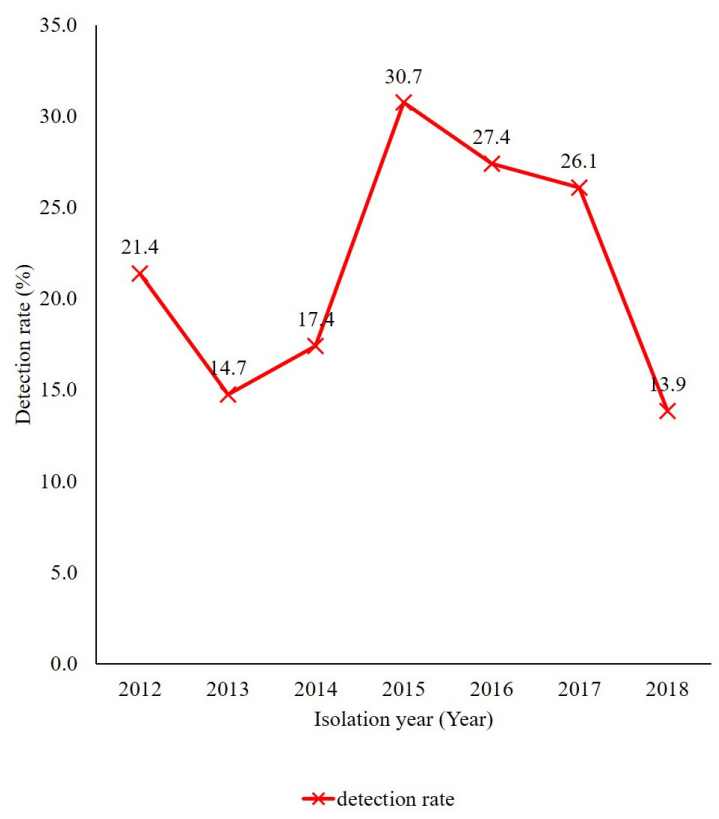

Figure 1. Annual positivity rate for respiratory specimens containing HRV isolated from Cheonan, Korea from January 2012 to December 2018. was the lowest (13.9\%; $\mathrm{N}=119 / 1435)$ during the study period (Figure 1). The detection rate in July was the highest (32.4\%; $\mathrm{N}=191 / 590)$, and the detection rate in February was the lowest (8.3\%; Figure 2, Table 1). The detection rate for patients 2 3 years old was the highest (36.5\%; $\mathrm{N}=212 / 581$ ), and the detection rate for patients $40 \sim 49$

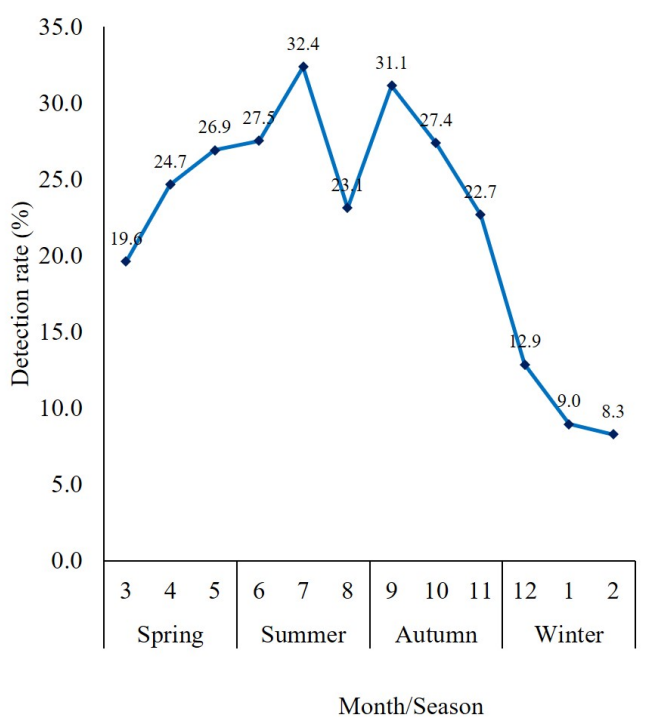

Figure 2. Detection rate of HRV aggregated by month in respiratory specimens isolated from Cheonan, Korea from January 2012 to December 2018.

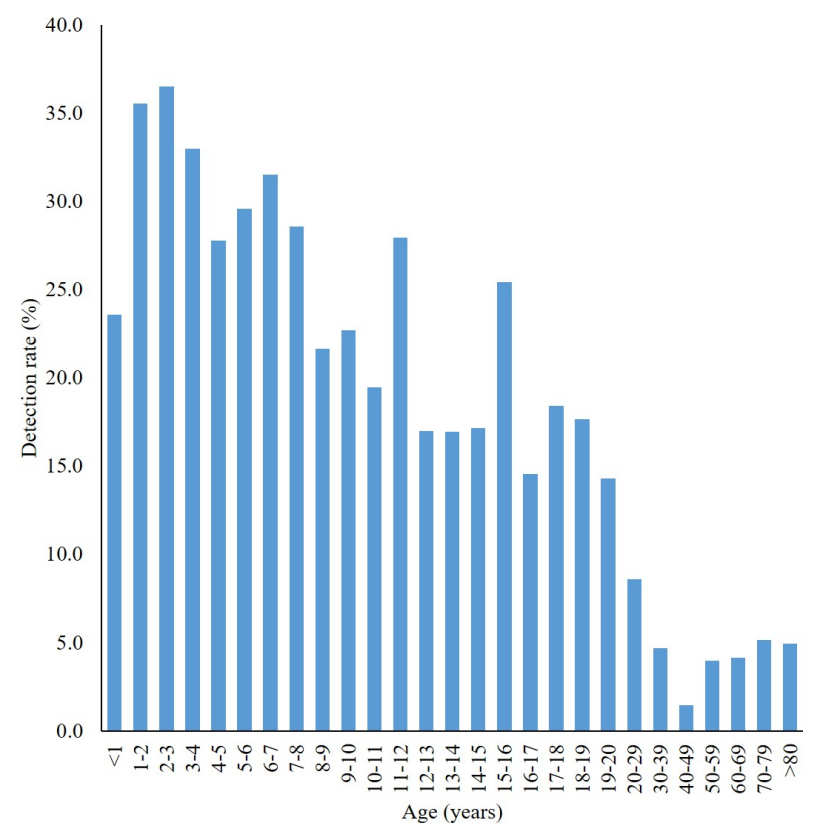

Figure 3. Detection rate of HRV aggregated by age in respiratory specimens isolated from Cheonan, Korea from January 2012 to December 2018. 
Table 2. Detection rate and number of specimen of HRV aggregated by age

\begin{tabular}{|c|c|c|c|}
\hline Age (year) & $\begin{array}{c}\text { Total } \\
\text { specimen (No.) }\end{array}$ & $\begin{array}{c}\text { Positive } \\
\text { specimen (No.) }\end{array}$ & $\begin{array}{l}\text { Detection } \\
\text { rate }(\%)\end{array}$ \\
\hline$<1$ & 3005 & 708 & 23.6 \\
\hline $1 \sim 2$ & 1047 & 372 & 35.5 \\
\hline $2 \sim 3$ & 581 & 212 & 36.5 \\
\hline $3 \sim 4$ & 364 & 120 & 33.0 \\
\hline $4 \sim 5$ & 299 & 83 & 27.8 \\
\hline $5 \sim 6$ & 230 & 68 & 29.6 \\
\hline $6 \sim 7$ & 181 & 57 & 31.5 \\
\hline $7 \sim 8$ & 147 & 42 & 28.6 \\
\hline $8 \sim 9$ & 120 & 26 & 21.7 \\
\hline $9 \sim 10$ & 97 & 22 & 22.7 \\
\hline $10 \sim 11$ & 72 & 14 & 19.4 \\
\hline $11 \sim 12$ & 68 & 19 & 27.9 \\
\hline $12 \sim 13$ & 53 & 9 & 17.0 \\
\hline $13 \sim 14$ & 59 & 10 & 16.9 \\
\hline $14 \sim 15$ & 70 & 12 & 17.1 \\
\hline $15 \sim 16$ & 59 & 15 & 25.4 \\
\hline $16 \sim 17$ & 55 & 8 & 14.5 \\
\hline $17 \sim 18$ & 38 & 7 & 18.4 \\
\hline $18 \sim 19$ & 17 & 3 & 17.6 \\
\hline $19 \sim 20$ & 14 & 2 & 14.3 \\
\hline $20 \sim 29$ & 105 & 9 & 8.6 \\
\hline $30 \sim 39$ & 128 & 6 & 4.7 \\
\hline $40 \sim 49$ & 209 & 3 & 1.4 \\
\hline $50 \sim 59$ & 326 & 13 & 4.0 \\
\hline $60 \sim 69$ & 483 & 20 & 4.1 \\
\hline $70 \sim 79$ & 717 & 37 & 5.2 \\
\hline$>80$ & 466 & 23 & 4.9 \\
\hline Total & 9010 & 1920 & \\
\hline
\end{tabular}

Table 3. Number of double infections with other respiratory viruses

\begin{tabular}{lc}
\hline \multicolumn{1}{c}{ Virus } & Number of multiple infections \\
\hline Adenovirus & 241 \\
Coronavirus 229E & 9 \\
Coronavirus OC43 & 21 \\
Influenza virus-A & 24 \\
Influenza virus-B & 11 \\
Metapneumovirus & 48 \\
Parainfluenza virus-1 & 38 \\
Parainfluenza virus-2 & 13 \\
Parainfluenza virus-3 & 85 \\
RSV-A & 78 \\
RSV-B & 63 \\
\hline
\end{tabular}

years old was lowest $(1.4 \% ; \mathrm{N}=3 / 209)$. The detection rate of patients less than 10 years old was the most highest (28.2\%, N=1,710/6,071); Figure 3, Table 2).

In total, 677 specimens showed multiple infections of HRV plus other respiratory viruses. Among multiple infections, 585 specimens showed double infections, 88 specimens showed triple infections, and four specimens showed quadruple infections. Among quadruple infections, two cases showed infections with HRV, Adenovirus, Coronavirus OC43, and RSV; one case showed infections with HRV, Adenovirus, Coronavirus OC43, and Parainfluenza virus-3; and one case showed infections with HRV, Adenovirus, Parainfluenza virus-1, and Parainfluenza virus-3. Among multiple infections, HRV and adenovirus were the most frequent multiple infections found (Tables 3 and 4).

\section{DISCUSSION}

In this study, we evaluated the detection rates of HRV in a cohort of 9,010 patients. Our results showed that HRV infections were most common in patients ages under 10 . Our findings provided insights into the prevalence of HRV in Korean populations.

During the period evaluated in our study, we observed two peaks in 2012 and 2015. Another study conducted over a similar period reported similar results, albeit with higher rates in 2011 and 2015 [8]. In Cheonan, HRV appeared to be an epidemic for a period of $2 \sim 3$ years. The prevalence period depends on the subtype of HRV [9]. For this reason, it seems to be an epidemic for a period of $2 \sim 3$ years.

The detection rate in July was the highest, followed by that in September. Detection rates averaged more than $15 \%$ per year, except for those $(9.0 \%$ and $8.3 \%$ ) in January and February, respectively. In previous studies, the incidence of HRV has been reported to increase in autumn and late spring, with lower rates during the other periods $[10,11]$. In contrast, high detection rates were reported in summer months (June and July), in Korea [10]. Moreover, the detection rates of HRV in June and July were higher than $20 \%$. Seasonal differences in respiratory viruses have been well documented [12]; however, the reason for this seasonality is unknown, and few studies have examined this topic $[2,13]$. As previously noted, we found that HRV was most active in Korea in the summer, which was unusual because another study reported that HRV is more 
Table 4. Number of triple infections with other respiratory viruses

\begin{tabular}{|c|c|c|c|}
\hline & Pat & gen & $\begin{array}{l}\text { Specimen } \\
\text { (No.) }\end{array}$ \\
\hline HRV & Adenovirus & Coronavirus 229E & 3 \\
\hline & & Coronavirus OC43 & 7 \\
\hline & & Influenzavirus-A & 3 \\
\hline & & Influenzavirus-B & 2 \\
\hline & & Metapneumo virus & 6 \\
\hline & & Parainfluenza virus-1 & 1 \\
\hline & & Parainfluenza virus-2 & 2 \\
\hline & & Parainfluenza virus -3 & 22 \\
\hline & & RSV-A & 10 \\
\hline & & RSV-B & 11 \\
\hline & Coronavirus 229E & Coronavirus OC43 & 1 \\
\hline & & Influenzavirus-A & 0 \\
\hline & & Influenzavirus-B & 0 \\
\hline & & Metapneumo virus & 3 \\
\hline & & Parainfluenza virus-1 & 0 \\
\hline & & Parainfluenza virus-2 & 0 \\
\hline & & Parainfluenza virus-3 & 0 \\
\hline & & RSV-A & 0 \\
\hline & & RSV-B & 0 \\
\hline & Coronavirus OC43 & Influenzavirus-A & 1 \\
\hline & & Influenzavirus-B & 0 \\
\hline & & Metapneumo virus & 1 \\
\hline & & Parainfluenza virus-1 & 0 \\
\hline & & Parainfluenza virus-2 & 0 \\
\hline & & Parainfluenza virus-3 & 3 \\
\hline & & RSV-A & 0 \\
\hline & & RSV-B & 2 \\
\hline & Influenzavirus-A & Influenzavirus-B & 0 \\
\hline & & Metapneumo virus & 0 \\
\hline & & Parainfluenza virus-1 & 0 \\
\hline & & Parainfluenza virus-2 & 0 \\
\hline & & Parainfluenza virus -3 & 0 \\
\hline & & RSV-A & 1 \\
\hline & & RSV-B & 1 \\
\hline & Influenzavirus-B & Metapneumo virus & 0 \\
\hline & & Parainfluenza virus-1 & 0 \\
\hline & & Parainfluenza virus-2 & 0 \\
\hline & & Parainfluenza virus -3 & 0 \\
\hline & & RSV-A & 0 \\
\hline & & RSV-B & 0 \\
\hline & Metapneumo & Parainfluenza virus-1 & 1 \\
\hline & virus & Parainfluenza virus-2 & 0 \\
\hline & & Parainfluenza virus -3 & 2 \\
\hline & & RSV-A & 1 \\
\hline & & RSV-B & 0 \\
\hline & Parainfluenza & Parainfluenza virus-2 & 0 \\
\hline & virus-1 & Parainfluenza virus-3 & 0 \\
\hline & & RSV-A & 0 \\
\hline & & RSV-B & 0 \\
\hline & Parainfluenza & Parainfluenza virus-3 & 0 \\
\hline & virus-2 & RSV-A & 1 \\
\hline & & RSV-B & 0 \\
\hline & Parainfluenza & RSV-A & 0 \\
\hline & virus-3 & RSV-B & 0 \\
\hline & RSV-A & RSV-B & 3 \\
\hline Total & & & 88 \\
\hline
\end{tabular}

likely to cause severe illness in winter and spring [12]. This may be because of unrelated factors; for example, yellow dust, which causes severe respiratory problems in the Asia-Pacific region, could cause an increase in the rate of HRV infection [14]. Although this has not yet been studied in Korea, similar results may be observed. Thus, further studies on the serotype, genotype, and seasonality of HRV are required to understand the causes of increased detection rates in the summer.

In Gwangju, Korea, researchers reported that detection rates decreased gradually with patient age. However, in this study, the detection rate was the lowest in the 40s and increased again in patients 50 years old and older. Previous studies have focused on pediatric patients; thus, there are not many studies on adults and the elderly. Respiratory virus infections are more common in elderly people with weakened immune systems, but can also affect young people with very strong immune systems, as demonstrated in this study. Therefore, further studies are required.

In our study, double infections with adenovirus were the most common. Other studies have reported higher rates of RSV co-infection [15]. RSV-A was identified in 78 cases, RSV-B was identified in 63 cases, and RSV was identified in 141 cases. Co-infection with adenovirus was also commonly observed. Further analyses of virus-host interactions and host immune responses are necessary to improve our understanding of co-infections with RSV.

Initial clinical symptoms are similar for most respiratory viruses, making it difficult to distinguish between causative pathogens based on clinical symptoms [16]. However, clinical severity varies according to the type of respiratory virus, subtype, and virus amount $[17,18]$. Co-infection with multiple viruses also affects the severity of the disease and has been reported to result in more severe infections than single infection [19]. However, in a separate study, co-infection was found to yield less-severe symptoms than single infection [20]. The growth of HRV is not significantly affected by the presence of other respiratory viruses, although studies have shown that the presence of HRV reduces the replication of other viruses [21]. Thus, the roles of respiratory viruses in co-infections are still 
unclear, and further studies are required.

The prevalence of HRV and the overall detection rate was highest in July during the Korean summer. In other countries, the HRV detection rates are not highest in July, highlighting a unique feature of HRV infection in Korea. Accordingly, it will be necessary to evaluate the cause of increased infections during the summer in Korea. Notably, the majority of positive samples (94.2\%) were collected from patients under 20 years of age. Further analysis showed that high detection rates were observed in patients 2 3 years of age. Moreover, HRV and adenovirus were the most frequent multiple infections found in our samples, and this correlation should also be evaluated. The range of epidemics was diverse, resulting in localized epidemics or simultaneous epidemics worldwide. Therefore, it is important to diagnose the causative virus early, prevent the abuse of antibiotics, and provide proper treatment. The results of our study could be helpful for the development of preventive guidelines for the treatment of respiratory virus infections.

This study is a retrospective study, and we therefore could not evaluate relationships with clinical symptoms in patients. Additionally, we did not assess the distributions of serotypes and genotypes. In future studies, it is necessary to study the distribution of serotypes, genotypes, and nucleotide sequences.

\section{요 약}

매년 호흡기 바이러스 감염으로 인해 수 백만명의 소아들이 사망한다. 호흡기 바이러스 감염의 원인 병원체 중 Human rhinovirus (HRV)는 코감기의 주요 원인 균으로 면역력이 약한 영, 유아, 노인 그리고 천식 환자에게 심각한 호흡기 감염의 원 인으로 작용하는 병원체이다. 2012년 1월부터 2018년 12월까 지 천안 단국대학교 병원 진단검사의학과에 호흡기 바이러스 검사가 의뢰된 호흡기 검체 9,010개의 검체를 real time reverse transcription PCR (real time RT-PCR) 방법으로 검 사했다. 총 12 종의 호흡기 바이러스를 real-time RT-PCR로 검 출했다. 연구기간 중 평균 검출률은 $21.3 \%$ 이었고, $\mathrm{HRV}$ 양성 환 자의 평균 연령은 6.5 세였다. 7 월의 검출률이 $32.4 \%$ 로 가장 높 게 나타났고 2 월이 $8.3 \%$ 로 가장 낮았다. 연령대별로 검출률을
분석해밨을 때 10 세 미만의 검출률이 가장 높았다. $\mathrm{HRV}$ 의 중복 감염률은 $35.3 \%$ 이고, 가장 흔한 조합은 Adenovirus와의 조합 이었다. 호흡기 바이러스 감염증은 비슷한 임상 증상을 가지고 있어 빠른 진단이 이루어 져야 적절한 시기에 적절한 치료를 할 수 있다. 호흡기 바이러스 감염은 보통 면역력이 약한 어린아이 와 노인에서 주로 발생하는 것으로 알려져 있다. 하지만 본 연구 에서는 10 세 미만에 이어 10 대 환자들의 검출률이 높았다. 그리 고 1,2 월을 제외하고 $15 \%$ 이상의 detection rate를 보였다. $\mathrm{HRV}$ 의 감염 양상에 대한 꾸준한 연구가 필요할 것으로 사료된다.

\section{Acknowledgements: None}

Conflict of interest: None

Author's information (Position): Jung BK ${ }^{1}$, M.D.; Kim $\mathrm{JK}^{2}$, Professor.

\section{REFERENCES}

1. Kim MR, Lee HR, Lee GM. Epidemiology of acute viral respiratory tract infections in Korean children. J Infect. 2000;41:152158.

2. Park JS. Acute viral lower respiratory tract infections in children. J Pediatr. 2009;52:269-276.

3. Kwak KJ, Kim YH, Choi HJ. Clinical characteristics of respiratory viral infection in children during spring/summer: focus on human bocavirus. Allergy Asthma Respir Dis. 2015;3:410-416.

4. Mäkelä MJ, Puhakka T, Ruuskanen O, Leinonen M, Saikku P, Kimpimäki M, et al. Viruses and bacteria in the etiology of the common cold. J Clin Microbiol. 1998;36:539-542.

5. Blomqvist S, Roivainen M, Puhakka T, Kleemola M, Hovi T. Virological and serological analysis of rhinovirus infections during the first two years of life in a cohort of children. J Med Virol. 2002;66:263-268.

6. Stone CA, Miller EK. Understanding the association of human rhinovirus with asthma. Clin Vaccine Immunol. 2016;23:6-10.

7. Korea Centers for Disease Control and Prevention. Korea Influenza and Respiratory Viruses Surveillance System [Internet]. Seoul: Korea Centers for Disease Control and Prevention; 2019 [cited 2019 Jun 28]. Available from: http://www.cdc.go. $\mathrm{kr} / \mathrm{npt} / \mathrm{biz} / \mathrm{npp} / \mathrm{portal} / \mathrm{nppPblctDtaMain.do?pblctDtaSeAt=3.}$

8. Lee SJ, Lee SH, Ha EK, Sheen YH, Sung MS, Jung Y, et al. Prevalence of respiratory virus infection with regard to age, sex, and seasonality factors: a single center experience against children hospitalized during the 10 years. Allergy Asthma Respir Dis. 2017;5:320-325.

9. Zhao Y, Shen J, Wu B, Liu G, Lu R, Tan W. Genotypic diversity and epidemiology of human rhinovirus among children with severe acute respiratory tract infection in Shanghai, 20132015. Front Microbiol 2018;9:1836.

10. Monto AS. Epidemiology of viral respiratory infections. Am J Med. 2002;112(Suppl 6A):4-12. 
11. Lee WM, Lemanske RF, Evans MD, Vang F, Pappas T, Gangnon $\mathrm{R}$, et al. Human rhinovirus species and season of infection determine illness severity. Am J Respir Crit Care Med. 2012;186: 886-891.

12. Fisman D. Seasonality of viral infections: mechanisms and unknowns. Clin Microbiol Infect. 2012;18:946-954.

13. Woo YR, Kim HJ, Kim MS, Koh HJ, Lee SG, Ahn YH. Clinical difference between single infection and coinfection with respiratory virus: the 2014 single-center study. Allergy Asthma Respir Dis. 2016;4:360-368.

14. Imaz MS, Sequeira MD, Videla C, Veronessi I, Cociglio R, Zerbini E, Carballal G. Clinical and epidemiologic characteristics of respiratory syncytial virus subgroups A and B infections in Santa Fe, Argentina. J Med Virol. 2000;61:76-80.

15. DeVincenzo JP, El Saleeby CM, Bush AJ. Respiratory syncytial virus load predicts disease severity in previously healthy infants. J Infect Dis. 2005;191:1861-1868.

16. Semple MG, Cowell A, Dove W, Greensill J, McNamara PS, Halfhide C, et al. Dual infection of infants by human metapneumovirus and human respiratory syncytial virus is strongly associated with severe bronchiolitis. J Infect Dis. 2005;191:382-
386.

17. Marguet C, Lubrano M, Gueudin M, Le Roux P, Deschildre A, Forget $\mathrm{C}$, et al. In very young infants severity of acute bronchiolitis depends on carried viruses. PLoS One. 2009;4:E4596.

18. Pinky L, Dobrovolny HM. Coinfections of the respiratory tract: viral competition for resources. PLoS One. 2016;11:E0155589.

19. International Committee on Taxonomy of Viruses. Genus: Enterovirus [Internet]. Washington: International Committee on Taxonomy of Viruses; 2019 [cited 2019 Jun 28]. Available from: https://talk.ictvonline.org/ictv-reports/ictv_online_report/ positive-sense-rna-viruses/picornavirales/w/picornaviridae/ 681/genus-enterovirus.

20. Yeo NK, Hwang YJ, Kim ST, Kwon HJ, Jang YJ. Asian sand dust enhances rhinovirus-induced cytokine secretion and viral replication in human nasal epithelial cells. Inhal Toxicol. 2010;22: 1038-1045.

21. Li H, McCormac MA, Estes RW, Sefers SE, Dare RK, Chappell JD, et al. Simultaneous detection and high-throughput identification of a panel of RNA viruses causing respiratory tract infections. J Clin Microbiol. 2007;45:2105-2109. 